\title{
Rejecting Academic Labor as a Subaltern Class: Learning from Paulo Freire and the Politics of Critical Pedagogy
}

\author{
Henry A. Giroux
}

While liberals, progressives, and left-oriented educators have increasingly opposed the right-wing assault on higher education, they have not done enough either theoretically or politically in connecting the issues of academic freedom, the proliferation of non-tenured and part-time faculty, and the state of critical pedagogy in the university. Although concern has been expressed about the shameless exploitation of non-tenured and part-time faculty in the United States (actually, an under-the-radar parallel alternative to the traditional tenure system), such concerns have not been linked to a full-spirited critique of the anti-democratic forces now affecting higher education through the relentless expansion of a growing managerialism and a neoliberal approach to university governance.[1]

The current labor crisis facing higher education shoul be addressed as part of a much broader assault on society by corporations, the military, right-wing foundations, and conservative religious groups. Higher education is a dangerous site because it offers the potential both for fostering critical thought and for shaping oppositional subject positions, identities, and social relations that could challenge the current neoliberal regime of ideology, politics, and economics. At the same time, it offers a space and modes of pedagogy that often unsettle many of the dominant orthodoxies and fundamentalisms that now dominate American culture. I believe that one way to challenge this military-industrial-academic complex is to make the question of pedagogy central to a reformulated politics that reclaims the university as a democratic public sphere. Pedagogy plays an important role in linking politics to matters of critical agency and social transformation. In this instance, pedagogy is integral to any discourse about academic freedom; but, more important, it might very well be the most crucial referent we have for understanding politics and defending the university as one of the few remaining democratic public spheres in North America today. As Ian Angus rightly argues, "The justification for academic freedom lies in the activity of critical thinking," [2] and protecting critical thought must involve safeguarding the pedagogical and political conditions that make it possible.

I believe that too many notions of academic freedom are defined through a privatized or individualized notion of freedom and are largely removed from the issue of democratic governance that is the primary foundation enabling academic freedom to become a reality in the first place. Right-wing notions of teaching and learning that seek to standardize curricula, impose an audit culture, and prioritize quantitative measures constitute a kind of antipedagogy, substituting conformity for dialogue and ideological inflexibility for critical engagement. Such attacks on critical thought should be named for what they are-an affirmation of thoughtlessness and an antidote to the difficult process of self- and social criticism.[3] In spite of what conservatives claim, right-wing pedagogy confuses training for education and enshrines a poisonous anti-intellectualism that produces a flight from thinking, the self, society, and the obligations of social responsibility. The outcome of this bare pedagogy of conformity-emptied of critical dialogue, critique, and ethical considerations - is not a student who feels a responsibility to others, but one who feels the presence of difference and troubling knowledge as an unbearable burden to be contained or expelled. In this way, it becomes apparent that the current right-wing assault on higher education is directed not only against the conditions that make critical pedagogy possible but also against the possibility of raising questions 
about the real problems facing higher education and society today, such as the increasing role of part-time labor, the instrumentalization of knowledge, the rise of an expanding national security state, the hijacking of public spheres by corporate and militarized interests, and the increasing attempts by right-wing extremists to turn education into job training and public pedagogy into an extended exercise in patriotic xenophobia. All of these efforts undermine the idea of the university as central to a functioning democracy in which people are encouraged to think, to engage knowledge critically, to make judgments, to assume responsibility for what it means to know something, and to understand the consequences of such knowledge for the world at large.

The rise of part-time labor in higher education is about both the increasing corporatization of the university and an insidious neoliberal ideology in which many groups, including students and faculty, are increasingly defined as either redundant, superfluous, or entirely disposable. As the university becomes subject to the growing politics of corporatization, the forces of privatization and contract labor have impacted on higher education in ways that suggest not only a shift in the governing structures of the university, now re-envisioned from the perspective of a new market-driven form of managerialism, but also a new formulation of faculty as a kind of subaltern class, unworthy of a voice in shaping the conditions of work or in governing the overall structure of the university. Even as the formative culture of a market-driven casino capitalism is denounced in the larger society because of the Katrina-like financial crisis it produced, higher education still defines itself largely as a corporation whose central mission is to reproduce the values and power relations of corporate culture. Many institutions of higher education, modeling themselves on the institutions and values at the heart of neoliberal power, have been ruthless in deeply undercutting the autonomy of faculty and graduate students while simultaneously engaging in one of the most invisible and unscrupulous examples of downsizing that has ever affected higher education. As William Pannapacker points out in The Chronicle of Higher Education, "According to the AAUP, between 1975 and 2007, the percentage of full-time tenure and tenure track faculty declined from 56.8 percent to 31.2 percent, while the number of parttime and non-tenure track faculty rose from 43.2 percent to 68.8 percent.'[4] Adjunct faculty are paid poverty level wages, often have no benefits, and are viewed as merely disposable labor. And yet, while the conditions under which they work and the role of the university in promoting them has to be subject to analysis, the larger understanding of both what the university should stand for and the importance of faculty in promoting a formative culture capable of sustaining democratic values and traditions must be part of any argument to improve the status of academic labor in the university. At stake here is convincing students, administrators, the larger public, and others that the fate of higher education as well as the fate of academic labor is about not just wages, power, and rights, it is also about the importance of modes of pedagogy, learning, and possibility that are central to sustaining and engaging a formative culture that can do much more than simply create job opportunities when it provides a crucial foundation for nurturing generations of students who are capable of expanding and deepening the structures, ideologies, and practices of an aspiring democracy. One crucial place to turn in order to understand the significance of critical pedagogy is to the work of the Brazilian radical educator, Paulo Freire.

Freire is one of the most important critical educators of the twentieth century.[5] Not only is he considered one of the founders of critical pedagogy, but he also played a crucial role in developing a highly successful literacy campaign in Brazil before the onslaught of the junta in 1964. Once the military took over the government, Freire was imprisoned for a short time for his efforts. He eventually was released and went into exile, primarily in Chile and later in Geneva, Switzerland for a number of years. Once a semblance of democracy returned to Brazil, he went back to his country in 1980 and played a significant role in shaping its educational policies until his untimely death in 1997. His book Pedagogy of the Oppressed is considered one of the classic texts of critical pedagogy and has sold over a million copies, influencing generations of teachers and intellectuals both in the United States and abroad. Since the 1980s there has been no intellectual on the North American educational scene who has matched either his theoretical rigor or his moral courage. Most colleges are now dominated by conservative ideologies, hooked on methods, slavishly wedded to instrumentalized accountability measures, and run by administrators who lack either a broader vision or a critical understanding of education as a force for strengthening the imagination and expanding democratic public life. Slavishly tied to a set of market values that have been devalued because of the current financial crisis, colleges largely define themselves in instrumentalized market terms-credentials and training now replace any vestige of critical education, and increasingly those disciplines, subjects, and elements of the university that are not defined in market terms are viewed as unviable and are either downsized or eliminated.

As the market-driven logic of neoliberal capitalism continues to devalue all aspects of the public interest, one consequence is that the educational concern with excellence has been removed from matters of equity while higher education, once conceptualized as a public good, has been reduced to a private good. Universities are now largely 
defined through the corporate demand that they provide the skills, knowledge, and credentials to build a workforce that will enable the United States to compete and maintain its role as the major global economic and military power. Consequently, there is little interest in understanding the pedagogical foundation of higher education as a deeply civic, political, and moral practice — that is, pedagogy as a practice for freedom. As schooling is increasingly subordinated to a corporate order, any vestige of critical education is replaced by training and the promise of economic security. Similarly, as pedagogy is now subordinated to corporate and military interests, academic labor is increasingly excluded from the process of governance, removed from tenure track lines, and treated as a disposable body of temporary workers. What this means is that academics are reduced to the status of technicians and deskilled as they are denied any control over their classrooms or power within school governance structures. Overworked and under-represented politically, an increasing number of higher education faculty are reduced to part-time positions, constituting a new subaltern class of academic labor.

But there is more at stake here than a crisis of authority, the exploitation of faculty labor, and the repression of critical thought. Too many classrooms at all levels of schooling now resemble a "dead zone" where any vestige of critical thinking, self-reflection, and imagination quickly migrate to sites outside of the school only to be corrupted by a corporate-driven media culture. Higher education furthers this logic by reducing its public vision to the interests of capital and redefining itself largely as a credentializing factory for students and a petri dish for downsizing academic labor. Under such circumstances educators rarely ask questions about how schools can prepare students to be informed citizens, nurture a civic imagination, or be self-reflective about public issues and the world in which they live. As Stanley Aronowitz puts it,

Few of even the so-called educators ask the question: What matters beyond the reading, writing, and numeracy that are presumably taught in the elementary and secondary grades? The old question of what a kid needs to become an informed 'citizen' capable of participating in making the large and small public decisions that affect the larger world as well as everyday life receives honorable mention but not serious consideration. These unasked questions are symptoms of a new regime of educational expectations that privileges job readiness above any other educational values.[6]

Unless the attack on academic labor is understood within the larger disciplinary measures at work in the university-measures that aim to eliminate any social formation that can potentially engage in critical pedagogy, challenge authority, and collectively assume power- the issue of contract labor will appear incidental to the larger transformations and politics now plaguing higher education. Put differently, higher education needs to be defended as a crucial public sphere, and faculty autonomy and student empowerment should be regarded as central and powerful components of that vision.

Against this regime of stripped down labor and "bare pedagogy" cleansed of all critical elements of teaching and learning, Paulo Freire believed that all education in the broadest sense was part of a project of freedom, and eminently political because it offered students the conditions for self-reflection, a self-managed life, and particular notions of critical agency. As Aronowitz puts it in his analysis of Freire's work on literacy and critical pedagogy:

Thus, for Freire literacy was not a means to prepare students for the world of subordinated labor or "careers," but a preparation for a self-managed life. And self-management could only occur when people have fulfilled three goals of education: selfreflection, that is, realizing the famous poetic phrase, "know thyself," which is an understanding of the world in which they live, in its economic, political and, equally important, its psychological dimensions. Specifically "critical" pedagogy helps the learner become aware of the forces that have hitherto ruled their lives and especially shaped their consciousness. The third goal is to help set the conditions for producing a new life, a new set of arrangements where power has been, at least in tendency, transferred to those who literally make the social world by transforming nature and themselves.[7]

What Paulo made clear in Pedagogy of the Oppressed, his most influential work, is that pedagogy at its best is about neither training, teaching methods, nor political indoctrination. For Freire, pedagogy is not a method or an a priori technique to be imposed on all students but a political and moral practice that provides the knowledge, skills, and social relations that enable students to explore the possibilities of what it means to be critical citizens while expanding and deepening their participation in the promise of a substantive democracy. Critical thinking for Freire was not an object lesson in test-taking, but a tool for self-determination and civic engagement. For Freire, critical thinking was not about the task of simply reproducing the past and understanding the present. To the contrary, it was about offering a way of thinking beyond the present, soaring beyond the immediate confines of one's experiences, entering into a critical dialogue with history, and imagining a future that would not merely reproduce the present. Theodor Adorno captures the spirit of Freire's notion of critical thinking by insisting that "Thinking is not the 
intellectual reproduction of what already exists anyway. As long as it doesn't break off, thinking has a secure hold on possibility. Its insatiable aspect, its aversion to being quickly and easily satisfied, refuses the foolish wisdom of resignation. ...Open thinking points beyond itself.'”[8]

Freire rejected those regimes of educational degradation organized around the demands of the market, instrumentalized knowledge, and the priority of training over the pursuit of the imagination, critical thinking, and the teaching of freedom and social responsibility. Rather than assume the mantle of a false impartiality, Freire believed that critical pedagogy must acknowledge that human life is conditioned — not determined — and recognize the crucial necessity of not only reading the world critically but also intervening in the larger social order as part of the responsibility of an informed citizenry. According to Freire, the political and moral demands of pedagogy should amount to more than the school and classroom being mere instruments of official power or assuming the role of apologists for the existing order-and they should amount to much more than the Obama administration seems to believe, given its willingness to give Bush's reactionary educational policies a new name and a new lease on life. Freire rejected those modes of pedagogy that supported economic models and modes of agency in which freedom is reduced to consumerism and economic activity is released from any value criterion except profitability and the neglect of a rapidly expanding mass of wasted humans. Critical pedagogy attempts to understand how power works through the production, distribution, and consumption of knowledge within particular institutional contexts and seeks to constitute students as informed subjects and social agents. In this instance, the issue of how identities, values, and desires are shaped in the classroom becomes the very grounds of politics. Critical pedagogy is invested in both the practice of self-criticism about the values that inform teaching and a critical self-consciousness regarding what it means to equip students with analytical skills to be self-reflective about the knowledge and values they confront in classrooms. Moreover, such a pedagogy attempts not only to provide the conditions for students to understand texts and different modes of intelligibility, but also to open up new avenues for them to make better moral judgments that will enable them to assume some sense of responsibility toward the other in light of those judgments.

Freire was acutely aware that what makes critical pedagogy so dangerous to ideological fundamentalists, the ruling elites, religious extremists, and right-wing nationalists all over the world is that central to its very definition is the task of educating students to become critical agents who actively question and negotiate the relationships between theory and practice, critical analysis and common sense, and learning and social change. Critical pedagogy opens up a space where students should be able to come to terms with their own power as critically engaged citizens; it provides a sphere where the unconditional freedom to question and assert is made central to the purpose higher education, if not democracy itself. And as a political and moral practice, way of knowing, and literate engagement, critical pedagogy attempts to "make evident the multiplicity and complexity of history." [9] History in this sense is engaged as a narrative open to critical dialogue rather than predefined text to be memorized and accepted unquestioningly. Pedagogy in this instance provides the conditions to cultivate in students a healthy skepticism about power, a "willingness to temper any reverence for authority with a sense of critical awareness." [10] As a performative practice, pedagogy takes as one of its goals the opportunity for students to be able to reflectively frame their own relationship to the ongoing project of an unfinished democracy. It is precisely this relationship between democracy and pedagogy that is so threatening to so many of our educational leaders and spokespersons today, and it is also the reason why Freire's work on critical pedagogy and literacy is more relevant today than when it was first published. Clearly, such a pedagogy demands not just a critical understanding of the relations between knowledge and power, learning and experience, and education and social change, but also a willingness to fight for the labor conditions that both promote academic freedom and struggle against academic repression. At the heart of any vestige of critical pedagogy is both the project of relating education to the creation of informed citizens and the labor conditions that give faculty the opportunity to engage in the pedagogies that make such a project possible. This is not merely a dispute over who should control the classroom, but a struggle over how power is shared, used, and institutionalized so as to create the structural and ideological conditions for experiencing the university as a democratic public sphere.

According to Freire, all forms of pedagogy represent a particular way of understanding society and a specific commitment to the future. Critical pedagogy, unlike dominant modes of teaching, insists that one of the fundamental tasks of educators is to make sure that the future points the way to a more socially just world, a world in which the discourses of critique and possibility in conjunction with the values of reason, freedom, and equality function to alter, as part of a broader democratic project, the grounds upon which life is lived. Such a future cannot be built on the backs of a subaltern class of academics who are powerless, overworked, denied basic benefits, and removed from shaping policy. Nor is the problem solved by simply calling for a limit to the pool of potential faculty. This is 
a political issue that is about power, the meaning of education, and what role faculty, students, and administrators are going to play in shaping a future much different than the present. This is hardly a prescription for political indoctrination in the classroom; rather, it is a project that gives critical education its most valued purpose and meaning, which is "to encourage human agency, not mold it in the manner of Pygmalion."[11] It is a position that also threatens right-wing private advocacy groups, neoconservative politicians, and conservative extremists. Such individuals and groups are keenly aware that critical pedagogy with its emphasis on the hard work of critical analysis, moral judgments, and social responsibility goes to the very heart of what it means to address real inequalities of power among faculty and administrators, or among others across society, and to conceive of education as a project for freedom while at the same time foregrounding a series of important and often ignored questions such as: What is the role of teachers and academics as public intellectuals? Whose interests does public and higher education serve? How might it be possible to understand and engage the diverse contexts in which education takes place? What is the role of education as a public good? How do we make knowledge meaningful in order to make it critical and transformative? How do we democratize governance? Against the right-wing view that equates any suggestion of politics with indoctrination, critical pedagogy is concerned with offering students new ways to think critically and act with authority as independent political agents in the classroom and in larger society; in other words, it is concerned with providing students with the skills and knowledge necessary for them to expand their capacities first to question the deep-seated assumptions and myths that legitimate the archaic and disempowering social practices structuring every aspect of society and then to take responsibility for intervening in the world they inhabit.

Education cannot be neutral. It is always directive in its attempt to teach students to inhabit a particular mode of agency, enable them to understand the larger world and one's role in it in a specific way, define their relationship, if not responsibility, to diverse others, and experience in the classroom some sort of understanding of a more just, imaginative, and democratic life. Pedagogy is by definition directive, but that does not mean it is merely a form of indoctrination. On the contrary, as Freire argued, education as a practice for freedom must expand the capacities necessary for human agency, and hence the possibilities for how academic labor should be configured to ensure such a project that is integral to democracy itself. Surely, this suggests that even within the privileged precincts of higher education, educators should nourish those pedagogical practices that promote "a concern with keeping the forever unexhausted and unfulfilled human potential open, fighting back all attempts to foreclose and pre-empt the further unravelling of human possibilities, prodding human society to go on questioning itself and preventing that questioning from ever stalling or being declared finished."[12] In other words, critical pedagogy forges an expanded notion of politics and agency through a language of skepticism and possibility, and a culture of openness, debate, and engagement-all those elements now at risk because of the current and most dangerous attacks on higher education. This was Paulo's legacy, one that invokes dangerous memories and is increasingly absent from any conservative discourse about current educational problems. Unfortunately, it is also absent from much of the discussion on the current status of academic labor.

For Freire, intellectuals must match their call for making the pedagogical more political with an ongoing effort to build those coalitions, affiliations, and social movements capable of mobilizing real power and promoting substantive social change both within and outside of the university. The struggle for better working conditions for faculty must be matched by the call for the university to fulfill its role as a democratic public sphere. In doing so, the call for faculty rights and power becomes connected and energized by a broader public discourse aimed at improving the unjust conditions that increasingly affect not only faculty but society in general.

Some of these demands are current being made by the Occupy Movement. Young people no longer recognize themselves in terms preferred by the market and they no longer believe in an education that ignores critical thinking, dialogue, and those values that engage matters of social responsibility and civic engagement. Nor do they believe in an education that treats them as disposable labor, a subaltern class of third rate workers. But students have more to offer than a serious critique of the university and its complicity with a number of anti-democratic forces now shaping the larger society, they are also modeling for faculty and others interested in education new modes of participatory democracy, and exhibiting forms of pedagogy and education that connect learning with social change and knowledge with more democratic modes of self-development and social empowerment--not unlike what Paulo Friere called for in his own pedagogy. Clearly, as faculty we have a lot to learn from both the ways in which students are changing the conversation about education, important social issues, democracy, and what it might mean to imagine a new understanding of politics and a different future. The questions students are raising are important for faculty to rethink those modes of professionalism, specialism, and social relations that have cut them off from addressing important social issues and the larger society. The Occupy protesters are right in arguing that higher education is a 
vital public sphere that should be at the forefront in addressing these issues. Moreover, faculty and administrators need to develop new modes of governance that both include student participation and voices and do what they can to offer up a new model of pedagogy, one that combines scholarly rigor and knowledge in an effort to help young people bridge the gap between the university and everyday life. Higher education should not be used to an benefit corporate interests or the warfare state, but to nurture and inspire existing and future generations of young people to take up the challenge of determining whether education will play a pivotal in enabling a future in which the claim on democracy will be fulfilled.

\section{Endnotes}

1. For an excellent analysis of contingent academic labor as part of the process of the subordination of higher education to the demands of capital and corporate power, see Marc Bousquet, How the University Works: Higher Education and the Low-Wage Nation (New York: New York University Press, 2008).

2. Ian Angus, "Academic Freedom in the Corporate University”, ed. Mark Cote, Richard J. F. Day, and Greig de Peuter, eds. Utopian Pedagogy: Radical Experiments against Neoliberal Globalization, (Toronto: University of Toronto Press, 2007), pp. 67-68.

3. These themes in Arendt's work are explored in detail in Elizabeth Young-Bruehl, Why Arendt Matters (New Haven: Yale University Press, 2006).

4. William Pannapacker, "The MLA and Academic Labor: From Marginality to Leadership," The Chronicle of Higher Education (December 30, 2009). Online: http://chronicle.com/blogPost/The-MALAcademicLabor-/19479.

5. One of the best sources on the life and work of Paulo Freire is Peter Mayo, Liberating Praxis: Freire's Legacy for Radical Education and Politics (New York: Praeger, 2004). Two of the best translators of Freire's work to the U.S. context are Donaldo Macedo, Literacies of Power (Boulder: Westview, 1994) and Ira Shor, Freire for the Classroom (Portsmouth, NH: Boynton/Cook, 1987).
6. Stanley Aronowitz, Against Schooling: For an Education That Matters (Boulder, CO: Paradigm Publishers, 2008), p. xii.

7. Stanley Aronowitz, "Forward," Critical Pedagogy in Uncertain Times: Hope and Possibilities, ed. Sheila L. Macrine (New York: Palgrave MacMillan, 2009), p. ix.

8. Theodor Adorno, "Education after Auschwitz," Critical Models: Interventions and Catchwords (New York: Columbia University Press, 1998), pp. 291-292.

9. Edward Said, Reflections on Exile and Other Essays (Cambridge: Harvard University Press, 2001), p. 141.

10. Said, Reflections on Exile and Other Essays, p. 501.

11. Stanley Aronowitz, "Introduction," in Paulo Freire, Pedagogy of Freedom (Boulder: Rowman and Littlefield, 1998), pp. 10-11.

12. Zygmunt Bauman and Keith Tester, Conversations with Zygmunt Bauman (Malden: Polity Press, 2001), p. 4. 